Joanna BAR

Pedagogical University of Krakow

jbar@up.krakow.pl

\title{
EAST AFRICAN COMMUNITIES \\ (1967-1978, 1999-) AND THEIR ACTIVITY \\ FOR POLITICAL STABILITY OF THE REGION
}

ABSTRACT The East African Community (EAC) is a regional intergovernmental organisation founded on 30 November 1999, including such member states as Burundi, Kenya, Rwanda, South Sudan, Tanzania, and Uganda. The EAC was meant as the reactivation and expansion of an earlier organisation founded in 1967 by Kenya, Tanzania and Uganda. Unlike its predecessor (which collapsed in 1978), not only has the contemporary Community been operating stably for almost 20 years, but it has also proved to be successful in improving the economic growth of its member states. Simultaneously, it supports the internal and national security of individual member states and the stability of the entire region. In recent years, the stabilisation capabilities of the Community have been tested through the accession of South Sudan, a country driven by a domestic conflict. Republic of South Sudan contributes not only rich crude oil deposits and water resources, but also a heavy burden of political issues in the form of both domestic conflicts and unresolved international problems such as a border conflict with the Republic of (north) Sudan. Successful economic cooperation may, however, reduce poverty and boost the development of South Sudan, both with regard to its economy and within the social and political aspects. This, in turn, may translate into good governance and the formation of a civil society.

Key words: East African Community, East Africa, Republic of South Sudan, sub-regional organisation, security, political integration 


\section{INTRODUCTION}

On May 25, 1963, in the capital of Ethiopia, Addis-Ababa, 32 independent African states recognized the Charter of the newly formed Organization of African Unity (OAU). The Organization has never gained supranational character. It had the status of a regional organization within the meaning of the rules adopted in Chapter VIII of the Charter of the United Nations. The main objective of the Organization of African Unity include activities for coordination of African cooperation with the outside world, strengthening the unity and solidarity of African countries, peaceful resolution of disputes while maintaining the territorial status quo and the principle of immunity to the internal affairs of the Member States; progress and elimination of all forms of colonialism and neo-colonialism and a declaration of non-attachment to any military blocks. ${ }^{1}$

The following decades of the 20th century showed that the OAU functioning in the difficult realities of the Cold War did not fulfil the hopes placed in it. The organization also failed to build the true unity of the continent's countries over the particular political conflicts of its members. Compliance with the principle of non-intervention in internal affairs of member countries resulted in the inability to effectively respond in cases of human rights violations.

At the end of the 20th century many leaders of individual African countries faced great political changes on a global as well as a regional scale. The end of the Cold War weakened the rivalry of the superpowers for influence in third world countries, and Africa came to the end of decolonization. This situation forced the necessity to change the priorities of the OAU; it was necessary to move to the efforts of the continent's economic development. Recalling the noble traditions of the Pan-African idea, referring to contemporary patterns and solutions of the European Union, it called for closer economic and political integration of the African continent. These ideas were expressed in the Treaty establishing the African Union, signed on July 11, 2000 in Lomé (Togo). In 2002, the Organization of African Unity was dissolved.

The first African sub-regional organizations, connected with the period of independence, began to be established in the 1960s. They were formed and developed in three waves, parallel to the activities of the Organization of African Unity.

In the 1960s, they benefited from political and economic ties from colonial times. Another impulse for the emergence of new sub-regional organizations or rebirths existing in the previous decade took place in the mid-1970s under the influence of the economic problems of the African continent, as well as successes achieved within the framework of European structures. Reaching for their models, they tried to implement them into African realities, at the same time creating the first coherent programs of

"Charter of the Organization of African Unity, 479 U.N.T.S. 39", University of Minnesota. Human Rights Library,13 September 1963, at <http://www1.umn.edu/humanrts/africa/OAU_Charter_1993.html>, 3 March 2015. 
cooperation and economic development, planned for implementation on the scale of the whole continent (Action Plan from Lagos).

At the beginning of the 1990s, revitalization of solutions adopted in previous decades, both organizational structures and development plans took place. These activities coincided with the establishment of the African Union, which took a superior position towards sub-regional institutions.

At present, in Africa, there are 8 Regional Economics Communities (RECs) ${ }^{2}$ operating actively under a superior organisation that is the African Union. Among these organisations, there is the East African Community (EAC), a regional intergovernmental organisation comprised of Burundi, Kenya, Rwanda, South Sudan, Uganda and Tanzania. Launched on 30 November 1999, it is one of the youngest sub-regional organisations in Africa and one of the most advanced ones with regard to the implementation of integration processes. ${ }^{3}$ The East African Community was established as the reactivation of an earlier organisation set up in 1967 (which collapsed in 1978), and expanded its original membership by the accession of new states.

The present paper aims at presenting the goals and directions of the activities of both organisations showing that, unlike its predecessor, over almost 20 years of its activity the contemporary Community has not only efficiently executed subsequent stages of economic integration, but also successfully works for achieving political stability within the South African region. The research questions of this article concern the extent to which the East African Community is able to support the internal and national security of individual member states (with special reference to South Sudan)and the stability of the entire region.

The choice of this research field coincides with the academic interests of the author that focus on political and social change in East African countries. A study on the selected African sub-regional organisation ${ }^{4}$ determined the choice of the research method: a case study analysis as a method is dominated by qualitative strategy, emphasising the broad context of events and uniqueness of the study subject, in combination with a thorough exploration of the subject matter with all its complexity and uniqueness.

The present paper is based on a critical analysis of resources (desk research), supported by critique and analysis of the available sources. Two monographs on the problems of African regionalism released in Poland turned out to be a valuable contribution to this study: Konrad Czernichowski's Integracja afrykaniska - uwarunkowania, formy wspótpracy, instytucje, 5 a work devoted to the economic aspects of African integration

UN Economic Commission for Africa, at <http://www.uneca.org/oria/pages/history-background-africas-regional-integration-efforts>, 2 March 2016.

3 W. Lizak, Afrykańskie instytucje bezpieczeństwa, Warszawa 2012, p. 425.

4 The notion of a 'sub-regional organisation' in this paper shall refer to intergovernmental organisations operating within a separable (most often, based on a geographical criterion) part of the African continent; the term 'regional organisation' was reserved for organisations active all over the African Union, author's note.

5 K. Czernichowski, Integracja afrykańska-uwarunkowania, formy wspótpracy, instytucje. Warszawa 2010. 
processes, and Wiesław Lizak's Afrykańskie instytucje bezpieczeństwa. ${ }^{6}$ They were complemented by articles released in collective works on the history and selected aspects of African regionalism by, among others, D. Bach, H. Dumała, W. Lizak and A. Polus. ${ }^{7}$

To date, no publication in Poland has been devoted entirely to the East African Community. The organisation was discussed only in subchapters of works on a broader scope of African studies, including the above-mentioned monographs by K. Czernichowski and W. Lizak. There are also no works on the East African Community in English. The subject matter is mentioned in chapters of monographs and article compilations (for example Msuya Waldi Mangachi, Regional Integration in Africa. East African Experience) ${ }^{8}$. Issues regarding the region were addressed in more detail by, among others, Eric Masinde Aseka in Transformational Leadership in East Africa, Politics, Ideology and Community ${ }^{9}$, and co-authors of a book edited by Felicia Arudo Yieke, entitled East Africa. In Search of National and Regional Renewal..$^{10}$ It is worth noting that the Internet has become the basic source of knowledge on the Community's works. The organisation's home site is the primary source of information on its structure, goals and current tasks. Electronic mail, as well as Facebook and Twitter, are the preferred channels for contacting its units. A well maintained website releases Community-developed resources (Reports \& Publications), such as statistical compilations, which are difficult to find in traditional bookstores and libraries. The Internet also offers information on on-going events in the Community member states; an all-community journal 'The EastAfrican' released online as both a standard and a mobile-friendly $W W W$ site is constantly updated, unlike its hard copy weekly counterpart. ${ }^{11}$ However, it must be emphasised that the sources listed above constitute only a brief selection from a broader compilation of literature on this subject, a complete list of which can be found in the bibliography.

Chronologically speaking, this article covers the years 1967 - 2016. The beginning of this period is marked by the foundation of the first East African Community, while the latter date marks the accession of South Sudan into the Community.

W. Lizak, Afrykańskie instytucje...

7 D. Bach, "Regionalizm, integracja i transnarodowa regionalizacja w Afryce", in K. Jędrzejczyk-Kuliniak, L. Kwieciński, B. Michalski, E. Stadtmüller (eds.), Regionalizacja w stosunkach międzynarodowych. Aspekty polityczno-gospodarcze, Torun 2008; H. Dumała, "Region Afryki" in I. Topolski, H. Dumała, A. Dumała (eds.), Regiony w stosunkach międzynarodowych, Lublin 2009; W. Lizak, "Regionalny system bezpieczeństwa w Afryce”, in E. Haliżak, R. Kuźniar, G. Michałowska et. al. (eds.), Stosunki międzynarodowe w XXI wieku. Księga jubileuszowa z okazji 30-lecia Instytutu Stosunków Międzynarodowych Uniwersytetu Warszawskiego, Warszawa 2006; A. Polus, "Regionalizm w Afryce Subsaharyjskiej”, PCSA Working Paper, January 2015, at <https://pcsa.org.pl/pcsa-working-paper-regionalizmw-afryceandrzej-polus/>, 17 September 2018.

8 M.W. Mangachi, Regional Integration in Africa. East African Experience, Ibadan 2011.

9 E.M. Aseka, Transformational Leadership in East Africa. Politics, Ideology and Community, Kampala 2005.

10 F.A. Yieke, East Africa. In Search of National and Regional Renewal, Dakar 2005.

11 See: The East African, at <http://www.theeastafrican.co.ke/>, 3 August 2012. 


\section{ORIGIN OF THE INTEGRATION OF EAST AFRICAN STATES}

The first African sub-regional organisations began to emerge in the 1960s, along with the formation of independent countries. These organisations were usually based on the structures of political and economic connections dating back to the colonial era. The East African Community (EAC) was established in 1967 as a result of a treaty between Kenya, Tanzania and Uganda, and was a typical example of a sub-regional organisation whose members were connected through the history of British colonialism and had experienced integration solutions in the colonial times.

Thus, the origin of the East African Community (EAC) is inseparable from the colonial past of East African countries. Kenya, Uganda and, since 1919, also Tanzania, have been seeking integration treaties for almost a century because, as early as in the 1890s, the British had implemented a cohesive policy in East Africa, determined by, for example, the need to secure control over lands along the upper Nile and monitor German activity in East Africa at the dawn of the Great War. Construction of a railway connection between the coast of the Indian Ocean and the most vital settlements and strategic points in Kenya and Uganda aimed at opening these lands up for the development of settlement, agriculture and trade. ${ }^{12}$ While executing and providing political support to these plans, the British decided in 1917 to create a custom union between Kenya and Uganda, with Tanganyika joining the two in $1927 .{ }^{13}$ In the years 1905 - 1940, that is before any official regional structures were formed by independent countries, common institutions were established for all British dominions in East Africa: The East African Currency Bill and Stamp, the East African Currency Board, the Postal Union, the Court of Appeal for Eastern Africa, the East African Governors' Conference, the East African Income Tax Board and the Joint Economic Council. The East African Airways Corporation' services reached beyond the East African region and the company provided connections to other parts of Africa, as well as to airports in both Europe and India. ${ }^{14}$

In 1948, the East African High Commission (EAHC) was established as a coordinating and supervisory body for the execution of common initiatives within the region: economic (among others, postal and customs union, developing uniform tariffs for external services), scientific and educational (for example, the East African University), ${ }^{15}$

12 B.I.M. Katembo, "Pan Africanism and Development. The East African Community Model", The Journal of Pan African Studies, vol. 2, no. 4 (2008), p. 108. Detailed information on the British railway investments in East Africa can be found at <http://www.mccrow.org.uk/eastafrica/eastafricanrailways/ KampalaNairobi.htm>, 8 March 2016.

13 "History of the EAC", East African Community, at <http://www.eac.int/about/EAC-history>, 7 March 2016.

14 "The History of the East African Community", East African Community, at <http://eacgermany.org/ eac-history/>, 8 March 2016.

15 The initiative had not been executed until 1963, compare: P. Poddar, D. Johnson (eds.), A Historical Companion to Postcolonial Thought in English, New York 2005, p. 489. 
transportation and communication (railway, harbours, airports, the telegraph), as well as a common department of meteorology. ${ }^{16}$

In 1961, following Tanganyika's independence, ${ }^{17}$ the East African Common Services Organisation (EASCO $)^{18}$ was founded to replace EAHC, whose structure became outdated after the colonial system collapsed. However, EASCO adopted a number of solutions and plans from its predecessor, but executed them within the new, changed political conditions. Along with regaining independence by the region's remaining countries (Uganda 1962, Kenya 1963), the leaders of newly sovereign states: Julius Nyerere (Tanzania), Milton Obote (Uganda), and Jomo Kenyatta (Kenya), urged for continued cooperation in joint integration ventures undertaken within the new political reality on the countries' own initiative and under independent leadership. A number of observers noticed a real chance to create a political federation based on the three said countries. However, this initiative was never executed due to a lack of actual common planning and shared fiscal policy, as well as Kenyas dominating position, the separate political interests of each individual member state and, first and foremost, the personal ambitions of their leaders.

\section{THE EAST AFRICAN COMMUNITY (1967- 1978)}

Only as late as in 1967, that is fifty years from the launch of the first regional cooperation between Kenya and Uganda, was the Treaty for East African Cooperation signed. Under the treaty, described as the "world's most advanced regional trade treaty" ${ }^{19}$ back in the day, the East African Community (EAC) and East African Custom Union were established.

The East African Community took over a number of institutions from the former EACSO. Its structure comprised 6 main administrative units: 1) the East African Authority, 2) the Committee of East African Ministers, 3) the Secretariat, 4) the East African Legislative Assembly, 5) the Ministerial Councils and 6) the East African Developmental Bank. Community investments and its services were classified into two groups: The East African Communities Corporation (EACC) supervised the railway, telecommunications and airways; while The General Fund Services (GFS) supervised budget management, conducted audits and controlled expenditures. ${ }^{20}$

The Community's priority goals included the creation of a common market, uniform customs tariffs and a similar scope of public services, all of which were to

16 B.I.M. Katembo, "Pan Africanism and Development..., p. 108.

17 Since 1964, independent Tanzania created from Tanganyika and Zanzibar.

18 "History of the EAC”..., 8 March 2016.

19 F.A.S.T. Matambalya, "Challenges of the EAC Common Market, in M. Stahl (ed.), Deepening East African Community (EAC) Integration, Dar es Salaam 2007, p. 46, also compare: at <http://eacgermany. org/eac-history/>, 8 March 2016.

20 B.I.M. Katembo, Scattered Assets. How African-Americans and Other Resources Can Shape $21^{\text {st }}$ Century Pan-African Empowerment, Bloomington 2012. 
contribute to a balanced economic growth throughout the region. The organisation had already functioned as a monetary union with a currency board and currency parity, achieved by acknowledging the equal value of the Ugandan, Kenyan and Tanzanian schilling. The fusion of public companies was planned in order to establish an all-East African railway, harbour and airways system (East African Railways and Harbours, East African Airways), postal service and the telegraph (East African Posts and Telecommunications), as well as the East African Development Bank. Other fields of integration included education with a uniform curriculum and a shared examination body (East African Examinations Council), as well as the East African University (with specialised colleges in each of the member states), the Inter-University Council of East Africa, and a publishing house (the East African Literature Bureau).

The citizens were free to travel across the community, and both skilled and unskilled workers were free to seek employment in other member states. The region was to become a huge common market for foreign investment.

The organisation was seated in Arusha (Tanzania). The decision not to locate the EAC Headquarters in Nairobi (and outside Kenya for that matter) developed as a correction to the earlier British model of the colonial era, in which Kenya - as one of the best developed East African countries in terms of its economy - was perceived as the most desired ground for the growth of European capital. The privilege of Kenya's capital city, Nairobi, resulted automatically in the marginalization of Tanzania, Zanzibar and Uganda, as well as Kenya's rural areas. The choice of Arusha for the official seat of the Community was related to the desire to promote the contribution and importance of all its part for the sake of successful integration activities.

The optimistic perspectives on permanent economic integration began to fall apart relatively early. As soon as in 1968, the East African Currency Board collapsed and ruined hopes for a quick and smooth transition into a monetary union. Subsequent years brought further failures.

From the contemporary perspective, we may assess that the failed attempt to implement the ideal of a Community resulted from a combination of political and economic factors. The lack of involvement of the private sector was surely an unfavourable phenomenon, as was the fact that decisions were taken by politicians in a downstream manner. ${ }^{21}$ No less important was the uneven distribution of regional integration benefits among the partner states. ${ }^{22}$ It seems, however, that the most important reason that doomed the initiative to failure was the lack of genuine cooperation between the leaders of the member states. Political cooperation collapsed when Idi Amin took power in Uganda (1971) and triggered a conflict with the President of Tanzania, Julius Nyerere; a conflict which evolved into a military attack on Tanzania executed by Uganda in 1978 .

Yet, in fact, the fall of this organisation began even earlier, in June of 1977, when the partner states withheld their approval for a new budget for the fiscal year beginning

21 R. Chande, "Achievements and Challenges of The EAC Customs Union”, in M. Stahl (ed.), Deepening East African Community (EAC) Integration (Preface), Dar es Salaam 2007, p. 22.

22 Preface: M Stahl (ed.), Deepening East African Community (EAC) Integration, Dar es Salaam 2007. 
on 1 July 1977. The member states did, however, seek for solutions to this deadlock. In September that same year in Washington, the ministers of finance of all the Community states signed the so-called protocol of agreement, committing themselves to find a solution with help from a generally accepted mediator, a Swiss diplomat Dr Victor H. Umbricht. His efforts, however, did not end the crisis. The Community Secretariat in Arusha terminated its activity in December 1978.

As it has been mentioned previously, the integration processes collapsed due to a number of reasons, including the lack of an effective and coherent concept for economic growth and a lack of willingness from the Community's political leaders -Tanzania’s President Julius Nyerere and Uganda's President Idi Amin in particular. The above-mentioned issues came on top of inefficient administration and long delays in the decision processes, which led to organisational chaos and confusion. Matters of social issues and civil liberties were never resolved. Other reasons for the collapse of the Community, as enumerated by W. Lizak, include economic tensions caused by an uneven level of development of the member states and differences resulting from Kenya's pro-Western orientation and socialist solutions promoted in Tanzania ${ }^{23}$. A decade later, V. Umbricht, the mediator appointed by the World Bank, described the consequences of the Community's dissolution in the following words: "The borders were closed. (...) There were no inter-country railways, no trade, no airways. We had no post and telecommunications services any more, no joint navigation. We even had a war in 1978-79 between Tanzania and Uganda ... And of course they did not pay their common debts. They not only had assets like railway wagons, they also had common liabilities, say, to the World Bank and to many governments, which they had to re-pay as a Community. But the Community having collapsed, nobody re-paid anything, so they were all in default. There was no way to see to it that liabilities would be honoured. The three countries lived so much apart from each other that they were unable to talk to each other anymore"24.

Negotiations on solutions to the issue of common financial liabilities of the former Community commenced only after the dictatorship of Idi Amin had ended (1979). As late as 1984, that is under Milton Obote's second presidential term, a mediation agreement was concluded with regard to the division of the Community's assets and liabilities. Pursuant to the agreement, the parties declared their willingness to identify potential fields for future cooperation as well and to create specific solutions to enable such cooperation, thus defining "further areas of future cooperation". 25

One of the treaty's tangible results was the formation of a three-sided working group set up in 1986 in order to define and develop potential forms of future cooperation. Five years later, in 1991, the Ministers of Foreign Affairs of Kenya, Tanzania and Uganda commenced works on establishing a new, pragmatic programme for the

23 W. Lizak, Afrykańskie instytucje..., p. 425; also compare: D. Mazzeo (ed.) African Regional Organizations, Cambridge 1984.

24 “The History of the East African Community”..., 17 September 2018.

25 "Mediation Agreement for the Division of Assets and Liabilities History of the EAC", East African Community, at <http://www.eac.int/about/EAC-history>, 19 September 2016. 
reactivation of cooperation abandoned years earlier; a tripartite expert committee was established to determine the area of common economic interest.

\section{THE EAST AFRICAN COMMUNITY (1999 -): REACTIVATION OR A NEW BEGINNING?}

On the cusp of the 1990s, solutions adopted in previous decades were being revitalised in various regions of Africa, both within the scope of organisational structures and development plans. Cooperation between sub-regional organisations was intensifying pursuant to guidelines adopted by the Conference on Security, Stability, Development and Cooperation in Africa held in Kampala (Uganda) in 1991, with expanding competence for improvement of regional security in mind.

Also in 1991, the Abuja Treaty (Nigeria) was signed in order to establish the African Economic Community (AEC). The execution of the treaty's main goal - transforming the continent into a single economic area, was planned for 34 years. During the transitional period, economic integration was to be executed at a sub-regional level by local organisations. The treaty assumed that in the initial stage, the existing sub-regional organisations would be supported (and possibly new ones founded), their forms of activity would be updated (for example, their websites were to be developed), new goals - both economic (promotion of good management practices, development of communication infrastructure, so that the lack of economic relations between regions in the previous years would not inhibit the development of trade) and political (care for regional security)- would be incorporated into these organisations' programmes.

In the case of the East African countries, there-integration process began in 1993 along with negotiations on establishing new tripartite cooperation programmes within such fields as policy, economy, social issues, culture, science and development of new technologies, defence and legal and judicial matters. In 1993, Kampala (Uganda) hosted the first meeting of leaders of the countries interested in re-launching the East African Community: Kenya (President Daniel Moi), Tanzania (President Ali Hassan Mwinyi), and Uganda (President Yoweri Museveni) aimed at discussing the future goals and the current political and economic conditions. During the meeting, a treaty was signed concerning establishment of the Permanent Tripartite Commission for East African Co-operation (PTC), which was launched on 30 November 1993. The Commission commenced its operations on 14 March 1996, along with the creation of Secretariat seated in Arusha.

The Kampala meeting became the first of many 'milestones', marking the actual construction process of the East African Community.

The Treaty for the Establishment of the East African Community was eventually signed on 30 November 1999 at the $4^{\text {th }}$ Arusha summit. The signers included Presidents Beniamin Mkapa (Tanzania), Daniel Moi (Kenya) and Yoweri Museveni (Ugan$\mathrm{da})$; back in the day, the treaty was nicknamed the ' $3 \mathrm{M}$ ' due to identical initials of the signers' family names. The treaty took effect on 7 July 2000 upon ratification by the 
three founding states - Kenya, Tanzania and Uganda - and thus the Community was reactivated with membership identical to its predecessor from the years 1967-1978.

The new East African Community (EAC) was established as a sub-regional intergovernmental organisation. It was founded to address the need for consolidation of cooperation between the three countries in the region - Kenya, Uganda and Tanzania. Despite the fact that the organisation's goals were dominated by the issues of economic growth, the documents adopted right before the Treaty was signed included the EAC Memorandum of Understanding on Co-operation in Defence.

In 2007, a decision was made to expand the Community trough accession of two new member states. On 18 June the same year, the Community was joined by Rwanda and Burundi (full membership from 1 July). Such a decision confirmed both the tangible success of the Community (the EAC Customs Union entered into force on 1 January 2005), as well as the desire to put the policy of preserving the historical tradition resulting from colonial affiliation (prior to World War I, Burundi and Rwanda belonged to German East Africa while, in the interwar period and after World War II, they were handed over to Belgium) in the past. A decade later, in 2016,the Republic of South Sudan acceded to the Community.

The organisation's goals are dominated by the issues of economic development and integration of member states. Economic cooperation in a market of almost 150 million participants ${ }^{26}$ is currently being executed within the scope of a customs union, a common market (which has become the first actual common market in the whole of Africa), and plans for establishing an East African Monetary Union in the first place.

A protocol on entering into a customs union was signed in 2004 and took effect in 2005 for a transitional period, while it was fully enforced in 2010. A protocol on establishing a common market was signed in 2009 and came into force in $2010 .{ }^{27}$ Currently, works on implementing the plan to form the East African Monetary Union (EAMU) - described as the third stage of EAC integration - are being conducted. The above-mentioned protocol was signed on 30 November 2013 in Kampala (Uganda) during the $15^{\text {th }}$ EAC summit, while a protocol on the introduction of a uniform currency-modelled on the European Union's Euro - and an all-Community central bank was signed in December 2013.

Apart from economic goals, long-distance political ones were also set, with the formation of a future political federation in mind. However, at present, the political cooperation within the East African Community aims at continuing the integration processes of its member states. ${ }^{28} \mathrm{~A}$ real desire to increase political integration is confirmed

26 "East African Community Facts and Figures (2016) Report", East African Community, at <https:// d3n8a8pro7vhmx.cloudfront.net/eatradehub/pages/3248/attachments/original/1493280329/eac_ facts_figures_2016_0.pdf?1493280329>, 17 September 2018.

27 "History of the EAC - Milestones in the EAC Integration Process", East African Community, at $<$ http://www.eac.int/index.php?option=com_content\&view $=$ article\&id $=44 \&$ Itemid $=54 \&$ limit start $=1>, 21$ February 2014.

28 "East African Community Facts and Figures (2012)", at <http://www.statistics.eac.int/index.php?option $=$ com_docman $\&$ task $=$ doc_view \&gid $=142 \& \mathrm{tmpl}=$ component $\&$ format $=$ raw \&Itemid $=153>$, 21 February 2014. 
by the involvement of politicians through both meetings of heads of state and government leaders within the Community Council and working meetings of its individual organs: the Council of Ministers, the Co-ordinating Committee, Sectoral Committees, the East African Court of Justice and the East African Legislative Assembly. A political federation was defined as the ultimate goal of regional integration within the EAC, whose implementation is planned upon the completed execution of the customs union, common market and monetary union. This goal is described in article 5 (2) of the Treaty for the Establishment of the East African Community and it is based on three pillars: a common foreign policy and security, good management and a successful execution of the previous stages of regional integration. ${ }^{29}$

Stable cooperation of all member states is needed not only for the sake of the organisation's mere existence, but also for efficient cooperation with external entities such as, for example, the European Union, whose aid is addressed rather at regional projects than individual countries' goals. In November 2007, Kenya, Uganda, Tanzania and Burundi - as EAC members - signed the Framework for an Economic Partnership Agreement (FEPA) with the European Union. Among this treaty's objectives, there are activities for economic growth, promoting regional integration, economic cooperation and good governmental practices within EAC counties, as well as strengthening the existing bonds among the parties based on solidarity and common interest. ${ }^{30}$ In October 2014 the East African Community finalised the negotiations with the EU for an Economic Partnership Agreement (EPA). The agreement reinforces cooperation on the sustainable use of resources and provides for further negotiations on services and trade-related rules in the future. The deal is in line with the EAC Common External Tariff and helps the EAC's efforts to get rid of non-tariff barriers in intra-EAC trade. ${ }^{31}$

It is also worth noting that European Union has maintained an arms embargo on Sudan since 1994. The ban covers South Sudan from the moment of its separation too.

\section{ACTIVITIES OF THE EAST AFRICAN COMMUNITY FOR THE POLITICAL STABILITY OF THE REGION}

Within the scope of international relations, the cooperation of the East African Community member states is executed, first of all, within the scope of processes aimed at maintaining peace and security within the region-issues traditionally related to dangers

29 "The Treaty for the Establishment of the East African Community", EAC Publication, vol. 14, no. 1 (2002), at <http://www.eala.org/uploads/The_Treaty_for_the_Establishment_of_the_East_Africa_Community_2006_1999.pdf>,17 September 2018.

30 P. Frankowski, I. Słomczyńska, Unia Europejska - Afryka Subsaharyjska. Uwarunkowania, mechanizmy; efektywność wspótpracy, Lublin 2011, p. 146.

31 More detailed information is available at "Factsheet on the Economic Partnership Agreements. The Eastern African Community (EAC)”, at <http://ec.europa.eu/trade/policy/countries-and-regions/ regions/eac/>, 3 July 2014. 
posed by an unstable borderline with Congo, Somalian terrorism and the internal conflicts taking place in South Sudan.

Since its inception in 1999, the EAC has taken steps to create a framework and structures operating in order to resolve on-going problems threatening the stabilisation of the member states and the entire region. With regional security in mind, the Strategy on Regional Peace and Security ${ }^{32}$ was adopted, and strategies for the elimination of trans-border crime and ensuring the safety of people and goods are being developed. These activities are based on article 124 of the Treaty for the Establishment of the East African Community, which acknowledges the need for ensuring peace and security in partner states. The same article presents comprehensive plans aimed at having a stable and secure environment within the region, as well as for supporting the development and peaceful life for all East African peoples.

To make these premises a reality, the EAC Council of Ministers appointed a group of experts and entrusted them with the task of developing a regional strategy for security with a supporting plan of its practical application. This strategy (Overview of Peace and Security Strategy) is concerned with common solutions for regional threats and ensuring the safety of citizens of Community member states. ${ }^{33}$ It was adopted at the Community Council of Ministers in November 2006, giving a green light for potential stabilisation interventions within the EAC. According to the strategy, the Peace and Security Sector is adapting dynamically to the nature and forms of constantly changing risks conditioned by technological advances, current issues of crime growth and international political events. The Strategy is flexible enough to adapt to these changes and may be easily amended in order to take newly emerging challenges regarding security threats into consideration. The Strategy covers cooperation for the eradication of crime: car theft, drug trafficking, terrorism, so-called money laundering and others.

Pursuant to the EAC Regional Strategy for Peace and Security, in order to tighten cooperation within the security sector, a Sectoral Council on Interstate Security was established. The adopted cooperation framework within international security, designed to supplement the existing bilateral agreements between security authorities within the region includes:

- implementation of the Protocol on Illicit Drug Trafficking (executed by a group of experts appointed especially for that task)

- Small Arms and Light Weapons Management Programmes (activity against the proliferation of small arms and light weapons was strengthened by launching an expert team to develop a regional weapons management policy), and

- cooperation on matters within the jurisdiction of a police force executed through meetings of heads of EAC police forces, and establishing a police liaison bureau within the structures of a proposed Directorate of Peace and Security.

32 "EAC Peace \& Security Strategy Overview", East African Community, at <http://eac.int/security/ index.php?option $=$ com_content\&view $=$ article\&id=67\&Itemid=143>, 22 June 2016.

33 "Overview of Peace and Security Strategy", East African Community, at <https://www.eac.int/security>, 17 September 2017. 
The EAC Secretariat coordinates implementation of common training programmes and activities for supervision of borders, as well as for increasing the efficiency of eradication of international crime. Law enforcement agencies in the EAC partner states cooperate with one another in order to stop trans-border crime-related activity, such as vehicle theft, smuggling, drug trafficking and human trafficking. Relevant authorities cooperate on returning stolen property and the extradition of crime suspects. Operations undertaken within the security sector involve the development and implementation of an early warning and counter-reaction system in the case of a conflict, as well as launching works within the scope of the EAC Regional Conflict Prevention, Management and Resolution. ${ }^{34}$

The matters of security within the region are directly related to the refugee issue, not only with respect to potential threats resulting from their influx, but also legal protection and material status of the emigrants themselves. To resolve the problem, in March 2010, a treaty was signed between the East African Community and the United Nations High Commission for Refugees (UNHCR) on cooperation of protection of emigrants' rights including, first and foremost, refugees, asylum seekers and internally displaced persons within the region..$^{35}$ One of the goals of the negotiations carried out at that time was to integrate international legal regulations with the domestic laws of the treaty's parties.

\section{ACCESSION OF SOUTH SUDAN AS A TEST OF THE EAC'S ABILITY TO STABILISE EAST AFRICA}

South Sudan acceded to the East African Community in 2016. Cooperation with the EAC provides the new member state - poorer than its neighbours - with an opportunity to boost its economic development and political stabilisation. Apart from rich deposits of crude oil and water resources, South Sudan brings to the table a number of political issues, including both internal conflicts and unresolved international problems including, above all, border conflicts with the Republic of (north) Sudan. For many commentators, the decision to accept South Sudan into the East African Community was associated with great risk for its stability and maintaining the current pace of integration processes.

The internal conflict in South Sudan had continued almost unabated since the country gained its independence in July 2011. According to the UN's data, as soon as in August 2011, over 1000 people were killed in South Sudan as a result of a power struggle between the Dinka, Nuer and Shilluk people and further armed clashes took place in in January 2012. ${ }^{36}$ The conflict began with the politicians' rivalry, but evolved in to an

34 "Peace and Security", East African Community, at <http://www.eac.int/sectors/peace-and-security>, 22 June 2016.

35 "UNHCR, EAC strengthens bilateral cooperation", East African Community, at <http://www.unhcr. org/cgi-bin/texis/vtx/refdaily?pass=463ef21123\&id=4cad5e165>, 4 July 2014.

36 "Walki plemienne w Sudanie. Ponad 150 zabitych", PAP, 4 January 2012, at <http://www.polskieradio.pl/5/3/Artykul/511746,Walki-plemienne-w-Sudanie-Ponad-150-zabitych>, 18 July 2016. 
ethnic war between the Nuer-dominated Riek Machar's rebels and the Dinka government under President Salva Kiir Mayardit. A civil war escalated at the turn of 2013 and 2014 and, accompanied by a still unresolved conflict with (north) Sudan, resulted in the country's actual collapse. Negotiations concerning a cease fire continued throughout the conflict and the leaders of the neighbouring countries - Uganda and Kenya in particular - played an important role at each stage of the conflict to prevent its internationalisation. Also, an internal struggle in the Central African Republic and repetitive attacks from Joseph Kony's Lord's Resistance Army (LRA), still unpacified, forced out of Uganda into the territory of the Democratic Republic of Congo, Central African Republic and South Sudan, contributed greatly to the destabilisation of the region. ${ }^{37}$

Due to the fact that the border between Uganda and Sudan features no natural obstacles and has always been peripheral, Uganda, along with Ethiopia and Kenya, was most concerned with restoring peace to South Sudan. The estimated number of Ugandan soldiers who served in South Sudan at the turn of 2013 and 2014, ensuring the safety of Juba airport and the city's most important offices, bridges and crossings on the river Nile, was about 2,000. The President of Uganda, Yoweri Museveni, was undoubtedly interested in incorporating South Sudan into Uganda's sphere of influence. Museveni also supported President Kiir in a dispute with his main political opponent, Riek Machar, keeping in mind that in 1980s and 1990s the latter helped, in compliance with Khartoum's policy, Ugandan rebels led by Joseph Kony, who is still wanted by the International Criminal Court (ICC) for war crimes. ${ }^{38}$ The support for President Museveni's policy resulted not only from immediate political and economic interest, but also from the shared history, because although the edge of the Sudd swamps naturally hampered contacts of southern Sudanese with the Arabs from the north of Sudan, a lack of such natural barrier in the south favoured contacts with neighbours, even if they considered Sudan's borderland as peripheries.

It was the shared history that created a favourable attitude towards the accession of South Sudan to the East African Community. An interpretation of this idea as an execution of mutual economic interests (the existing Community members would benefit from advantageous prices of South-Sudanese oil, while South Sudan would take advantage of partnership terms of oil transport through a designed pipeline to the Port of Lamu in Kenya) seems to be an oversimplification. Undoubtedly, South Sudan needs reliable geopolitical and economic anchors capable of aiding its development processes, but in reality, from the very beginning of the accession procedure, the existence of a complex network of interconnections was as obvious as the fact that it should be interpreted as a sort of balance of gains and losses incurred by all parties in

M. Kurcz, "Granica, transgraniczne migracje i Armia Oporu Pana. Perspektywa Sudanu Południowego i Ugandy”, in W. Cisło. J. Różański, M. Ząbek (eds.), Bilad as-Sudan. Kultury i migracje, Warszawa 2013.

38 W. Jagielski, “Żandarm znad Nilu. Jak prezydent Ugandy Yoweri Museveni zaprowadza pokój w Sudanie Południowym", PAP, 16 January 2014, at <http://konflikty.wp.pl/kat,132874,title,Zandarm-znadNilu-Jak-prezydent-Ugandy-Yoweri-Museveni-zaprowadza-pokoj-w-Sudanie-Poludniowym,wid, 16335105,wiadomosc.html?ticaid=11752a\&_ticrsn=5>, 7 July 2016. 
the negotiations - South Sudan on the one hand, and the older members of the East African Community on the other.

On 2 November 2015, South Sudan applied for accession into the East African Community once again during a summit of heads of states and government leaders of the EAC countries. Representatives of the South Sudanese government admitted that not all of the accession criteria had been met and, although the country has opened up its economy for the Community members, they still have a lot of work to do with regard to management, democracy, security and human rights. The South Sudanese Minister of Foreign Affairs, Barnaba Marial Benjamin, argued that Rwanda and Burundi faced similar problems and yet they were accepted into the EAC in June 2007, claiming that South Sudan “...stands a better chance for resolving its problems faster and more efficiently as an EAC member". 39

'Anchoring' in a regional block that has been proving its stability for over a dozen years also gave South Sudan hope for help in building a long-term domestic peace. The Sudanese expected that Community membership will act like an extra dividend after a peace treaty has been achieved, which will enable construction of an independent judiciary system and democratic institutions and, at the same time, will be helpful in overcoming the disadvantageous effects of the country's geographical location. ${ }^{40}$ These hopes are finally to become reality. On 12 September 2018, President of South Sudan, Salva Kiir, and the opposition leader Riek Machar, signed a peace treaty during a regional summit in Ethiopia. The treaty concluded peace negotiations commenced on 30 June this year, which resulted in the ceasefire announced on 30 June, followed by a truce signed on 6 June, under which the conflicted government's and rebel's armies were withdrawn from urban areas..$^{41}$ It is certainly a long awaited step towards the stabilisation of the country, although it does not guarantee that the long-lasting conflict has been actually ended. Another peace treaty was signed in May 2014, but did not bring the expected effects: an armistice and formation of a transitional government. However, the Transitional Government of National Unity (TGoNU) was established in the spring of 2016, at the brink of South Sudan's accession into the East African Community. ${ }^{42}$

While working to ensure permanent peace in South Sudan, EAC sought to cooperate with other institutions. The East African Community cooperated with the United Nations in tackling conflicts in South Sudan in efforts to promote peace within the region. On April 2018 the East African Community has applied to become part of the Intergovernmental Authority for Development (IGAD) South Sudan peace process to

39 F. Oluoch, "East Africa: South Sudan's Push to Join EAC Gains Momentum”, The East African, 2 November 2015, athttp://allafrica.com/stories/201511090602.html, 13 July 2016.

40 “South Sudan becomes EAC's sixth member state”, Sudan Tribune, 3 February 2016, at http://sudantribune.com/spip.php?article58197, 21 July 2016.

41 "Sudan Południowy: Prezydent i lider opozycji podpisali porozumienie pokojowe", Interia fakty świat, 12 February 2018, at <https://fakty.interia.pl/swiat/news-sudan-poludniowy-prezydent-i-lideropozycji-podpisali-porozu,nId,2630416>, 18 September 2018.

42 "Transitional Government of National Unity (TGoNU) of the Republic of South Sudan", 11 May 2016, at <http://embassy-southsudan.de/transitional-government-of-national-unity-tgonu-ofthe-republic-of-south-sudan/>, 18 September 2018. 
allow lawmakers of the East African Legislative Assembly get involved in the talks between the different factions in the South Sudan conflict. ${ }^{43}$

The level of involvement of individual EAC members in the process was certainly different. The restoration of peace in South Sudan was most significant for Uganda (for security reasons) and Kenya (for economic reasons).

It is difficult to assess precisely to what extent the efficiency of the on-going peace process is determined by the development of South Sudan within the EAC structures and how significant was the impact of UN's sanctions on the course of events. Nevertheless, the experiences of Rwanda accepted into the Community in 2007 proves that EAC membership may contribute not only to economic growth (and thus to a decrease in poverty levels), but also to political stabilisation preconditioned by these processes.

\section{CONCLUSION}

Despite the doubtless successes achieved so far, the Community constantly faces new challenges that they need to rise to in order to prevent the organisation from following in the footsteps of its predecessor, which only managed to survive for a decade due to a lack of willingness to cooperate from the member states' leader, among other factors. Nowadays, such cooperation between the heads of member states is smooth, although mutual animosity is still present, most often voiced by Tanzanian politicians who reproach Kenya, Rwanda and Uganda for closer cooperation with one another than with other countries.

Within the scope of foreign affairs, the most crucial challenge faced by the Community members has been restoring stability (nowadays - maintaining it) at the border with the Democratic Republic of Congo (DRC), which has been a turbulent area since 1994. Obviously, Rwanda and Uganda are the ones most interested in peace since both border on the Congolese province of North Kivu.

A lack of stability on the Community's north borderline worries Uganda and Kenya, especially because the borders are barely marked by distinct geographical features. Uganda suffered from the civil war in South Sudan, while Kenya has been and still is at risk of terrorist attacks from Islamic militants from the Somali group al-Shabaab. The EAC is not a military organisation, and its main objective is to achieve political and economic integration of its member states. Due to the current geopolitical situation, collective work against Somali terrorism and ensuring security in the region have also become important goals for the organization. The EAC Protocol on Peace and Security is currently awaiting ratification by the member states. The Protocol urges the EAC Council of Ministers to support introducing decisions taken to ensure peace and security, and to strengthen the region's potential with regards to effective preventing, fighting and eliminating terrorism in all its forms and manifestations, as well as preventing terrorists from purchasing any weapon of mass destruction and blocking all means of

43 "EALA MPs want to help break deadlock in South Sudan peace talks", NTV, 23 April 2018, at <http://www.ntv.co.ug/news/international/4522060-4545608-mpfdn2z/index.html>, 12 December 2012. 
transporting such a weapon. This resolution calls on the member states to seal any loopholes related to funding acts of terrorism, and to denounce using modern technologies, especially the Internet, as means of recruiting terrorists. ${ }^{44}$

Conflicts in the north-eastern parts of the Democratic Republic of Congo, the civil war in South Sudan and threats from Islamic militants from al-Shabaab are not the only problems that put the region's stability at jeopardy. On top of that, there is a lack of stability in the Central African Republic and potential threats from Joseph Kony's Lord's Resistance Army (LRA), which has not been fully pacified yet and whose units were active not long ago within the Democratic Republic of Congo, the Central African Republic and the Republic of South Sudan.

Undoubtedly, the accession of South Sudan (2016) into the EAC should be considered as one of the activities aimed at achieving the region's stability; however, it was a test of the Community's ability to ensure the stability and harmonious growth of its member states. As mentioned above, Republic of South Sudan contributes not only rich crude oil deposits and water resources, but also a heavy burden of political issues in the form of both domestic conflicts and unresolved international problems such as a border conflict with the Republic of (north) Sudan. The acceptance of the Republic of South Sudan into the Community did not result so much from political implications and historical connections as from potential economic gains, including wider access to South Sudanese oil deposits and water resources, and the fact that South Sudan would become the largest export market for other Community members, although this opportunity is currently limited by poor infrastructure. Successful economic cooperation may, however, reduce poverty and boost the development of South Sudan, both with regard to its economy and within the social and political aspects. This, in turn, may translate into good governance and the formation of a civil society. Thus, we should hope that also this time the Community's bold accession policy which, in 2007, opened up an opportunity for faster growth of Burundi and Rwanda, will bring tangible economic benefits to all interested parties and will visibly improve the citizens' standard of living and enhance stability in the East African region.

\section{BIBLIOGRAPHY}

Aseka E.M., Transformational Leadership in East Afrika. Politics, Ideology and Community, Kampala 2005.

Bach D., "Regionalizm, integracja i transnarodowa regionalizacja w Afryce", in K. JędrzejczykKuliniak, L. Kwieciński, B. Michalski, E. Stadtmüller (eds.), Regionalizacja w stosunkach międzynarodowych. Aspekty polityczno-gospodarcze, Toruń 2008.

44 "EALA Wants Partner States to Infuse Mechanism for Speedy Implementation of Peace and Security Decisions in the Region", East African Community, 24 May 2015, at <http://www.eac. int $/$ index.php?option $=$ com_content $\&$ view $=$ article $\& i d=1890$ : eala-wants-partner-states-to-infuse-mechanism-for-speedy-implementation-of-peace-and-security-decision-in-the-region\&catid=146:press-releases\&Itemid=194>, 21 August 2015. 
Bar J., "Polityka państw Wspólnoty Wschodnioafrykańskiej wobec kryzysu w Regionie Wielkich Jezior", in A. Żukowski (ed.), Konteksty bezpieczeństwa w Afryce. Konflikty, wojny, polityka bezpieczeństwa, "Forum Politologiczne", vol. 17, Olsztyn 2014.

Bar J., "Współpraca polityczna i gospodarcza w ramach Wspólnoty Wschodnoafrykańskiej (EAC) jako przykład nowych form komunikowania w Afryce”, in A. Żukowski (ed.), Komunikowanie w Afryce. Endo-i egzogeniczne aspekty: Polityka - gospodarka - spoteczeństwo media, "Forum Politologiczne", vol. 19, Olsztyn 2016.

Booth D., Cammack D., Kibua T. et al., "East African integration: How can it contribute to East African development?", Briefing, February 2017, at <https://www.odi.org/sites/odi. org.uk/files/odi-assets/publications-opinion-files/126.pdf >.

"Charter of the Organization of African Unity, 479 U.N.T.S. 39”, University of Minnesota. Human Rights Library, 13 September 1963, at <http://www1.umn.edu/humanrts/africa/ OAU_Charter_1993.html>.

Cisło W., Różański J. Ząbek M. (eds.), Bilad as-Sudan. Kultury i migracje, Warszawa 2013.

Czernichowski K., Integracja afrykańska - uwarunkowania, formy wspótpracy, instytucje, Warszawa 2010.

“EAC Peace \& Security Strategy Overview”, East African Community, at <http://eac.int/security/index.php?option $=$ com_content $\&$ view $=$ article $\& i d=67 \&$ Itemid $=143>$.

"EALA Wants Partner States to Infuse Mechanism for Speedy Implementation of Peace and Security Decisions in the Region", East African Community, 24 May 2015, at <http://www. eac.int $/$ index.php?option $=$ com_content $\&$ view $=$ article $\&$ id $=1890$ : eala-wants-partnerstates-to-infuse-mechanism-for-speedy-implementation-of-peace-and-security-decision-inthe-region \& catid=146: press-releases $\&$ Itemid $=194>$.

"EALA MPs want to help break deadlock in South Sudan peace talks", 23 April 2018, NTV, at <http://www.ntv.co.ug/news/international/4522060-4545608-mpfdn2z/index.html>.

"East African Community Facts and Figures - 2012", at <http://www.statistics.eac.int/index. php?option $=$ com_docman $\&$ task $=$ doc_view \&gid $=142 \&$ tmpl $=$ component $\&$ format $=$ raw \&Itemid $=153>$.

East African Community Facts and Figures (2016) Report, East African Community Secretariat, November 2016, at <https://d3n8a8pro7vhmx.cloudfront.net/eatradehub/pages/3248/ attachments/original/1493280329/eac_facts_figures_2016_0.pdf?1493280329>.

"East African Railways and Harbours. Kampala to Nairobi", at <http://www.mccrow.org.uk/ eastafrica/eastafricanrailways/KampalaNairobi.htm>.

"Fact sheet on the Economic Partnership Agreements. The Eastern African Community (EAC)", Europan Commission, February 2014, at <http://ec.europa.eu/trade/policy/ countries-and-regions/regions/eac/>.

Francis D.J., Uniting Africa. Building Regional Peace and Security Systems, Aldershot 2006.

Frankowski P., Słomczyńska I. (eds.), Unia Europejska - Afryka Subsaharyjska. Uwarunkowania, mechanizmy; efektywność wspótpracy, Lublin 2011.

"History of Africa's Regional Integration Efforts", UN Economic Commission for Africa, at <http:// www.uneca.org/oria/pages/history-background-africas-regional-integration-efforts $>$.

"History of the EAC", East African Community, at <http://www.eac.int/about/EAC-history>. "History of the EAC - Milestones in the EAC Integration Process", East African Community, 
at $<$ http: $/ /$ www.eac.int/index.php?option=com_content\&view=article\&id=44\&Itemid= 54\&limitstart $=1>$.

Jagielski W., "Żandarm znad Nilu. Jak prezydent Ugandy Yoweri Museveni zaprowadza pokój w Sudanie Południowym", PAP, 16 January 2014, at <http://konflikty.wp.pl/kat,132874, title,Zandarm-znad-Nilu-Jak-prezydent-Ugandy-Yoweri-Museveni-zaprowadza-pokoj-wSudaniePoludniowym,wid, 16335105 , wiadomosc.html?ticaid $=11752 \mathrm{a} \&$ _ticrsn $=5>$.

Katembo B.I.M., "Pan Africanism and Development: The East African Community Model", in The Journal of Pan African Studies, vol. 2, no. 4 (2008).

Katembo B.I.M., Scattered Assets. How African-Americans and Other Resources Can Shape $21^{\text {st }}$ Century Pan-African Empowerment, Bloomington 2012.

Law B., "AFRICOM hosts East African Community Delegation", United States Africa Command, 9 December 2015, at <http://www.africom.mil/newsroom/article/23996/africomhosts-east-african-community-delegation $>$.

Lizak W., Afrykańskie instytucje bezpieczeństwa, Warszawa 2012.

Lizak W., „Regionalny system bezpieczeństwa w Afryce”, in E. Haliżak, R. Kuźniar, G. Michatowska (eds.), Stosunki międzynarodowe w XXI wieku. Księga jubileuszowa z okazji 30-lecia Instytutu Stosunków Międzynarodowych Uniwersytetu Warszawskiego, Warszawa 2006.

Makinda S.M., Okumu F.W., The African Union. Challenges of Globalization, Security and Governance, New York 2008.

Mangachi M.W., Regional Integration in Africa. East African Experience, Ibadan 2011.

Mazzeo D. (ed.), African Regional Organizations, Cambridge 1984.

"Mediation Agreement for the Division of Assets and Liabilities History of the EAC", East African Community, at <http://www.eac.int/about/EAC-history $>$.

Oluoch F., "East Africa. South Sudan's Push to Join EAC Gains Momentum", The East African, 2 November 2015, at <http://allafrica.com/stories/201511090602.html>.

"Overview of Peace and Security Strategy", at $<$ https://www.eac.int/security $>$.

"Peace and Security", East African Community, at <http://www.eac.int/sectors/ peace-and-security $>$.

Poddar P., Johnson D. (eds.), A Historical Companion to Postcolonial Thought in English, New York 2005.

Polus A., "Regionalizm w Afryce Subsaharyjskiej", PCSA Working Paper, no. 1 (2015), at $<$ https://pcsa.org.pl/pcsa-working-paper-regionalizm-w-afryceandrzej-polus/>.

Repinski G., Stahl H.M., Poverty and Poverty Reduction Strategies in the East African Community (EAC), Moshi 2005.

"South Sudan becomes EAC's sixth member state", Sudan Tribune, 3 February 2016, at < http:// sudantribune.com/spip.php?article58197>.

Stahl M. (ed.), Deepening East African Community (EAC) Integration, Dar es Salaam 2007.

"Sudan Południowy. Prezydent i lider opozycji podpisali porozumienie pokojowe”, Interia fakty świat, 12 February 2018, <https://fakty.interia.pl/swiat/ news-sudan-poludniowy-prezydent-i-lider-opozycji-podpisali-porozu,nId,2630416>.

"The History of the East African Community", East African Community, at <http://eacgermany.org/eac-history/>.

"The Treaty for the Establishment of the East African Community", EAC Publication, vol. 14, 
no. 1 (2002), at <http://www.eala.org/uploads/The_Treaty_for_the_Establishment_of_ the_East_Africa_Community_2006_1999.pdf $>$.

Topolski I., Dumała H., Dumała A. (eds.), Regiony w stosunkach międzynarodowych, Lublin 2009.

“Transitional Government of National Unity (TGoNU) of the Republic of South Sudan”, Embassy of the Republic of South Sudan in Germany, 11 Mai2016, at <http://embassy-southsudan. $\mathrm{de} /$ transitional-government-of-national-unity-tgonu-of-the-republic-of-south-sudan/ >.

Ugirashebuja E., Ruhangisa J.E., Ottervanger T.R., Cuyvers A., East African Community Law. Institutional, Substantive and Comparative EU Aspects, Brill Nijhoff 2017.

"UNHCR, EAC strengthens bilateral cooperation”, East African Community, at <http:// www.unhcr.org/cgi-bin/texis/vtx/refdaily?pass $=463 \mathrm{ef} 21123 \& \mathrm{zid}=4 \mathrm{cad} 5 \mathrm{e} 165>$.

"Walki plemienne w Sudanie. Ponad 150 zabitych", PAP, 4 January 2012, at <http://www.polskieradio.pl/5/3/Artykul/511746,Walki-plemienne-w-Sudanie-Ponad-150-zabitych>.

Yieke F.A. (ed.), East Africa. In Search of National and Regional Renewal, Dakar 2005.

Prof. Joanna BAR, Ph.D - political scientist, historian and ethnologist; associate professor at the Institute of Political Science of the Pedagogical University of Krakow, Chair of Political Systems. Her research field centers around the social and political change in east African countries, with a particular focus on contemporaries social and political changes in Rwanda and Tanzania. She has conducted fieldwork in several countries in Sub-Saharan Africa. 